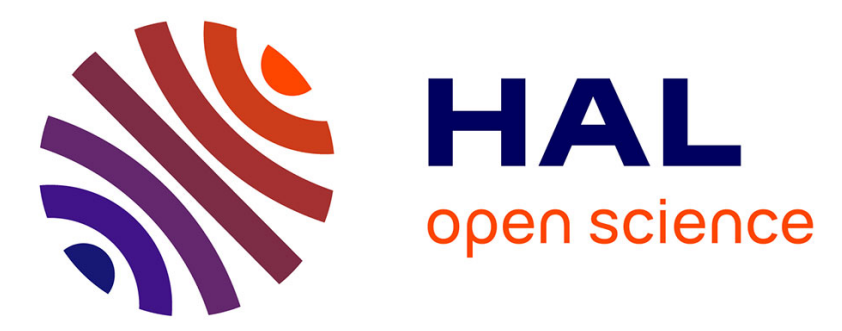

\title{
Reduced sexual dichromatism, mutual ornamentation, and individual quality in the monogamous Zenaida dove Zenaida aurita
}

Aurélie Quinard, Frank Cézilly, Sébastien Motreuil, Jean-Marc Rossi, Clotilde

Biard

\section{To cite this version:}

Aurélie Quinard, Frank Cézilly, Sébastien Motreuil, Jean-Marc Rossi, Clotilde Biard. Reduced sexual dichromatism, mutual ornamentation, and individual quality in the monogamous Zenaida dove Zenaida aurita. Journal of Avian Biology, 2016, 48 (4), pp.489-501. 10.1111/jav.00902 . hal01447919

\section{HAL Id: hal-01447919 https://hal.sorbonne-universite.fr/hal-01447919}

Submitted on 27 Jan 2017

HAL is a multi-disciplinary open access archive for the deposit and dissemination of scientific research documents, whether they are published or not. The documents may come from teaching and research institutions in France or abroad, or from public or private research centers.
L'archive ouverte pluridisciplinaire HAL, est destinée au dépôt et à la diffusion de documents scientifiques de niveau recherche, publiés ou non, émanant des établissements d'enseignement et de recherche français ou étrangers, des laboratoires publics ou privés.

\section{()(1)(2)}

Distributed under a Creative Commons Attribution - ShareAlikel 4.0 International 
Reduced sexual dichromatism, mutual ornamentation, and individual quality in the monogamous Zenaida dove, Zenaida aurita.

Aurélie Quinard ${ }^{1}$, Frank Cézilly ${ }^{1,2}$, Sébastien Motreuil ${ }^{1}$, Jean-Marc Rossi ${ }^{3}$ and Clotilde Biard $^{3}$

${ }^{1}$ Université de Bourgogne-Franche Comté, UMR CNRS 6282 Biogéosciences, Dijon, France

${ }^{2}$ Institut Universitaire de France

${ }^{3}$ Sorbonne Universités, UPMC Univ Paris 06, UPEC, Paris 7, CNRS, INRA, IRD, Institut d'Écologie et des Sciences de l'Environnement de Paris, F-75005 Paris, France.

Corresponding author: Clotilde Biard, Institut d'Écologie et des Sciences de l'Environnement de Paris, Université Pierre et Marie Curie - UPMC, 4, place Jussieu, case 237, F-75005 Paris, France. E-mail: clotilde.biard@upmc.fr

Decision date: 02-Aug-2016

This article has been accepted for publication and undergone full peer review but has not been through the copyediting, typesetting, pagination and proofreading process, which may lead to differences between this version and the Version of Record. Please cite this article as doi: [10.1111/jav.00902]. 


\section{Summary}

Although variation in plumage coloration is known to occur both between and within sexes, its study remains limited to a few bird families. The Zenaida dove, Zenaida aurita, is a socially monogamous tropical columbid bird species, characterized by an overall cinnamon-brownish plumage and structural colorations on the head and neck. The species has been described as sexually dichromatic for plumage, although color differences between males and females are not obvious in the field. We investigated variation in the presumably melanin-based color of the crown, mantle, breast, and belly, in the iridescent dark-blue streaks on the head, and in the symmetric iridescent patches on the neck, over the whole spectrum visible to birds. Further, unlike most previous studies, we assessed covariation between plumage color and phenotypic traits in both males and females in relation to the putative signaling function of ornaments. Zenaida doves appeared to be slightly sexually dichromatic for the hue of pigment-based colored areas, with males being on average more reddish than females. However, this difference was not discernible when considering the avian visual system. Conversely, although the reflectance spectra of iridescent plumage did not significantly differ between sexes in brightness, chroma or spectral position of the peaks, color discrimination analyses showed that individuals should be able to perceive between- or within-sex differences in the color of the iridescent patch. In addition, several color parameters of brown and iridescent feathers were significantly related to territorial status, body condition, wing chord, and, albeit weakly, to individual multilocus heterozygosity. Overall, our results thus suggest that plumage color might be a reliable signal of quality in individuals of both sexes in this species. Further studies are needed to test the potential implication of plumage coloration in mate choice and mating patterns in the Zenaida Dove.

Keywords: female ornamentation, heterozygosity, plumage color, sexual selection, iridescence, melanin,

\section{Zenaida aurita}




\section{Introduction}

Among bird species, a high inter-individual variation can be observed in adult plumage colour. Part of this variation can be accounted for by the existence of sexual dichromatism, i.e. a difference in color patterns between the two sexes (Badyaev and Hill 2003). Ever since Darwin (1871), it has been assumed that the extent of sexual dichromatism partly reflects variation in mating system and the intensity of sexual selection (Andersson 1994; but see Gluckman 2014). Accordingly, comparative studies have shown that, overall, the extent of avian sexual dichromatism is much reduced in socially monogamous species compared to polygamous ones (Scott and Clutton-Brock 1990, Owens and Hartley 1998, Dunn et al. 2001), and increases with the intensity of sexual selection (Figuerola and Green 2000). There are, however, several exceptions to this rule (Owens and Hartley 1998, Badyaev and Hill 2003), and, in particular, some monogamous species initially classified as sexually monochromatic based on human vision, have later been found to be sexually dichromatic in UV wavelengths (Andersson et al. 1998, Hunt et al. 1998, Mahler and Kempenaers 2002, Mennill et al. 2003, Mays et al. 2004, Eaton 2005).

In addition to sexual dichromatism, continuous or discrete variation in adult plumage colour may also exist between individuals within each sex. Such variation can be under the influence of both genetic and environmental factors (Roulin and Dijkstra 2003, Reudink et al. 2015), and is often associated with fitness differences in terms of survival (Hõrak and Maenniste 2016) or reproductive success (Kruger and Lindstrom 2001, Brommer et al. 2005). In addition, inter-individual variation in plumage coloration, through being an honest signal of phenotypic and/or genetic quality, may have a signaling function during social interactions and mate choice.

Both sexual dichromatism and within-sex variation in bird plumage coloration can correspond to variation in structural ultraviolet or visible coloration (Cuthill et al. 1999, Shawkey et al. 2005), iridescence (Osorio \& Ham 2002), or pigment-based coloration of feathers mainly due to carotenoids (Badyaev and Hill 2000), psittacofulvins (Taysom et al. 2011), porphyrins (Negro et al. 2009), or melanin (Meunier et al. 2011), the latter being the most common mechanism of color production in birds (McGraw et al. 2005, Hubbard et al. 2010). Whereas carotenoid-based coloration in feathers is generally considered to be a reliable signal of the quality of an individual (Møller et al. 2000, MacDougall and Montgomerie 2003, Peters et al. 2008, Murphy et al. 2009), the condition-dependence and signaling function of structural colors and melanin-based plumage ornaments remain debated (Siefferman et al. 2005, Griffith et al. 2006, Korsten et al. 2007, Maia and Macedo 2010, Murphy and Pham 2012, Piault et 
al. 2012, Parker 2013, D’Alba et al. 2014, Musgrove and Wiebe 2016; for recent reviews, see GuindreParker and Love 2014, Roulin 2016).

Sexual dichromatism and inter-individual variation in plumage coloration have been studied in a wide range of species (i.e. Badyaev and Hill 2003, Eaton 2005, Bókony et al. 2008, Galván and Møller 2013). However, although the family Columbidae includes about 310 species that show a large variation in both plumage coloration and the extent of sexual dichromatism (del Hoyo et al. 1997), only a few studies have provided quantitative measurements of plumage coloration in pigeons and doves, essentially focusing on feral pigeons (McGraw 2004, Yin et al. 2006, Yoshioka et al. 2007; but see Dyck 1987). One noticeable exception, however, is the study by Mahler and Kempenaers (2002) on the Picui dove, Columbina picui, showing the existence of an ultraviolet sexual dichromatism.

The socially monogamous Zenaida dove, Zenaida aurita, is a Caribbean endemic columbid species (Bond 1993), characterized by a cinnamon-brownish plumage, with light buff-brown chest and underparts, metallic pink-purple gloss on lateral and lower portions of hind necks, and dark iridescent blue streaks above and below ear coverts (del Hoyo et al. 1997). The overall brownish coloration of this granivorous dove is presumably due to melanin pigmentation, as carotenoid pigmentation is rare among columbids and strictly limited to frugivorous species (Mahler and Kempenaers 2002). The Zenaida dove has been reported as being sexually dichromatic according to plumage hue in identification guides and in the literature (Wiley 1991, del Hoyo et al. 1997, Gibbs et al. 2001, Sol et al. 2005). It has been in particular claimed that female Zenaida doves can be readily distinguished from males by their duller and less reddish plumage, and by the absence or reduced size of the iridescent pink-purple patches on the neck (Wiley 1991, del Hoyo et al. 1997, Gibbs et al. 2001, Sol et al. 2005). However, it has been more recently argued that such differences are not quite obvious, such that the sexing of Zenaida doves by plumage color might not be a reliable method (Monceau et al. 2011).

Through the detailed analysis of plumage reflectance spectra in the Zenaida dove, we i) present here the first assessment of sexual distinguishability of plumage coloration considering the avian visual system in a Columbidae, and ii) investigate the relationship between plumage color and individual quality. Focusing on presumably melanin-based and iridescent plumage areas, we first estimated both the extent of sexual dichromatism, and the extent of variation in plumage coloration within each sex, using reflectance spectrometry over the UV and visible range of light spectra, combined with molecular sexing. We then evaluated to what extent the observed variation could be perceived by the avian visual system. Finally, we considered the potential signaling function of coloration through its relationship with body 
size (wing chord), body condition, territorial status, and level of heterozygosity (as a measure of genetic quality that might be reflected in plumage coloration; Bolund et al 2010) as potential signals of individual quality.

\section{Methods}

\section{Study species, study sites and sample size}

The Zenaida dove is a granivorous columbid species characterized by long-term pair-bonding and yearround breeding and territoriality (Wiley 1991, Quinard and Cézilly 2012). The species shows a slight sexual dimorphism, with males being on average 2-5\% larger than females, although size distribution shows a large overlap between sexes (Dechaume-Moncharmont et al. 2011). Juveniles can be distinguished from adults based on morphological characteristics (plumage development and bill morphology, Wiley 1991, del Hoyo et al. 1997, Gibbs et al. 2001), but age cannot be ascertained when birds are first captured as adults.

The data presented here come from a long-term study of the Barbados (West Indies) population of Zenaida doves. There, individuals may either actively defend, alone or in pairs, a territory against conspecifics, or feed with very little aggression towards conspecifics in large aggregations at specific sites where food availability is particularly high (Dolman et al. 1996, Carlier and Lefebvre 1996). Individuals feeding in flocks are significantly smaller than territorial individuals, and are presumably floaters or poorly competitive individuals that have not yet obtained access to a territory (Sol et al. 2005, Monceau et al. 2011). On the other hand, once individuals have become territorial, they tend to remain so for the rest of their life, even after having lost their mate through death or divorce (Quinard 2013, F. Cézilly unpubl. data). As in other parts of the range of the species (Wiley 1991), breeding occurs year-round, but with a peak in breeding activity during the "high" breeding season, i.e. from January to April (F. Cézilly unpubl. data.). Territorial individuals were caught using clap-net traps in the Sunset Crest residential area and the Folkestone Park, both located near Holetown $\left(13^{\circ} 10^{\prime} 60 \mathrm{~N}, 59^{\circ} 38^{\prime} 60 \mathrm{~W}\right)$. Non-territorial individuals feeding in large groups were trapped at Roberts Manufacturing Co. Ltd. (13 $\left.{ }^{\circ}{ }^{\prime} 6 \mathrm{~N}, 59^{\circ} 34^{\prime} 48 \mathrm{~N}\right)$, a pet and livestock food factory. On each capture, wing chord was measured with a ruler (accuracy: $\pm 1 \mathrm{~mm}$ ), and tarsus length with a digital caliper (accuracy: $\pm 0.2 \mathrm{~mm}$ ). Individuals were weighed using a digital scale (accuracy: $\pm 0.1 \mathrm{~g}$ ). In addition, a blood 
sample $(40 \mu l)$ was taken on each ringed bird by puncturing the brachial vein and stored in $800 \mu \mathrm{L}$ of storage buffer (70\% ethanol and 30\% Tris-EDTA buffer $\mathrm{pH}$ 8) (Monceau et al. 2011). Finally, color was measured on different areas of the plumage (see below) before releasing the bird at the site of capture. Only adults were considered in this study. Sex of individuals was later identified using molecular markers (see Monceau et al. 2011 for details).

Data were collected during both the high breeding season (from 1 March to 9 April 2012 and from 18 February to 19 March 2013) and the low breeding season (from 12 November to 2 December 2012). Data were obtained for a total of 122 individuals, 73 caught at the Sunset Crest and Folkestone areas and 49 caught at the Roberts site. Of these, 60 were females and 62 were males. Two birds were captured twice during two different sessions. For these individuals, we used the data recorded during the first session.

\section{Microsatellite genotyping and individual heterozygosity}

We genotyped 122 individuals across 11 polymorphic microsatellite markers developed especially for the Zenaida dove by Monceau et al. (2009) using the LI-COR Genotyping System (see Monceau et al. 2009 for a full description of the genotyping method). Tests for linkage disequilibrium (LD) and HardyWeinberg equilibrium (HWE) were computed using GENEPOP (v. 4.1.4.; Rousset 2011) and were found to be non-significant. We also found no evidence for identity disequilibrium (ID), i.e. a correlation in heterozygosity and/or homozygosity across loci (Szulkin et al. 2010). As an estimate of individual heterozygosity, we computed the multilocus heterozygosity coefficient (MLH) as recommended by Szulkin et al. (2010). MLH corresponds to the proportion of heterozygous loci within an individual, replacing missing values by the locus population mean. MLH varies between 0 , when all loci are homozygous, and 1, when all loci are heterozygous.

\section{Plumage color measurements}

The dorsal plumage of Zenaida doves varies from brownish to cinnamon, while ventral plumage is light vinaceous to white, with black spots on the wings. The outer secondary feathers and the outer tail feathers 
bear white tips. The sides of the neck are characterized by an iridescent pink/violet patch and two dark violet-blue streaks which appear black from a distance (Fig.1a, b; Wiley 1991, Bond 1993).

Compared to humans, birds possess an additional cell cone type in the retina, receptive to ultraviolet light (UV, 300-400nm) above 340nm (Chen et al. 1984). Columbidae species appear to possess the "VS" rather the "UVS" cone type (Romeski and Yager 1976, Cserháti et al. 1989, Ödeen and Håstad 2013, more details in Supplementary material), indicating that their maximum light absorption ranges between 402 and $426 \mathrm{~nm}$ rather than between 355 and $380 \mathrm{~nm}$. It is therefore likely that the Zenaida dove's vision is also sensitive to UV light, with, presumably, a "VS" visual system.

Feather coloration was assessed in the field using a JAZ-EL200 spectrometer, supplied with a Jaz PX pulsed short arc Xenon lamp module and a $400 \mu \mathrm{m}$ fibre-optic probe (Ocean Optics, IDIL Fibres Optiques, Lannion, France), kept at a constant distance and a constant angle $\left(90^{\circ}\right)$ from the plumage surface, following a previously published protocol (Andersson and Prager 2006; details in Supplementary material). Reflectance was measured for each bird on six body regions, namely the crown, mantle, breast, belly (between the legs), iridescent patch and lower dark streak on both sides of the neck. Reflectance of each body region was recorded three times at the same point, removing the spectrometer probe between each measurement. All measurements were made by the same person (AQ).

The crown, mantle, breast and belly reflectance spectra were characterized by a peak in the UV, followed by a slow increase in reflectance towards the red wavelengths (Supplementary material Fig. Ala, b, c, and d, respectively). Dark streaks on the neck also showed reflectance spectra characterized by a peak in the UV-blue, albeit less important and flatter than for other body regions, while the rest of the spectra was almost flat (Fig. A1e). Finally, iridescent patches on the lower neck typically showed multiple peaked spectra (McGraw 2004), with a first peak in the UV-blue wavelengths, a second peak in the blue-green wavelength, and a third peak in the red wavelengths (Fig. A1f).

Upon observation of reflectance spectra for all body regions, and based on previously published methods (Montgomerie 2006), different parameters were chosen to describe reflectance spectra, and calculated using the Color Project 1 software (version 4.3) developed by JMR. For all body regions, brightness, the total intensity of light reflected by feathers, was calculated as the integral of reflectance 
over [300, 700] nm (e.g. Endler 1990, Andersson et al. 1998). For the crown, mantle, breast and belly, UV chroma was calculated as the relative proportion of the total reflectance in the ultraviolet part of the spectrum visible to birds $\left(\mathrm{R}_{340-400} / \mathrm{R}_{300-700}\right)$ (spectral purity, e.g. Andersson et al. 1998). We also calculated yellow-red chroma as the relative proportion of the total reflectance within a range from 550 $\mathrm{nm}$ to $700 \mathrm{~nm}$ of the spectrum $\left(\mathrm{R}_{550-700} / \mathrm{R}_{300-700}\right)$. For the crown, mantle, breast and lower belly, we additionally assessed hue as an angle value $\left(0^{\circ}:\right.$ red $-90^{\circ}$ : yellow $)$ that is correlated with the wavelength of maximum slope, and calculated the sign of this slope using the Endler's segment classification (Endler 1990). Although this parameter does not take into account the UV part of the spectrum to which birds are sensitive and is adapted to trichromatic vision only, hue was used in order to compare our data to previously reported variation in color as assessed from the human eye (see Introduction). Finally, ultraviolet, blue-green, and red peaks of the iridescent patch were described by their spectral position (spectral position of maximum reflectance e.g. Delhey and Kempenaers 2006) and their chroma (wavelength of maximum reflectance, and relative proportion of reflectance in the ranges [340, 400], $[390,550]$ and $[550,700] \mathrm{nm}$, respectively). Mean and s.d. values for each color parameter are given in Supplementary material Table A1.

\section{Correlations among color parameters}

Correlations among variables describing plumage color of the four brown areas on the one hand and of the iridescent patch on the other hand, were investigated using non-parametric correlation matrices based on Spearman's rank method. For the crown, mantle, breast and lower belly, correlation matrices were computed separately for hue, brightness, yellow-red chroma and UV chroma. Correlations among the variables describing the color of the iridescent patch were computed separately (Supplementary material Table A2). Hue values for the mantle, crown and breast were moderately correlated (from $R_{S}=0.12, P=$ 0.08 to $\left.R_{S}=0.36, P<0.001\right)$. Belly hue was positively correlated to breast hue $\left(R_{S}=0.28, P=0.002\right)$, but not to crown or mantle hue $(P>0.05)$. Brightness values for the mantle, crown and breast were significantly and positively correlated between themselves, as were yellow-red chroma values $\left(0.40<\mathrm{R}_{\mathrm{S}}\right.$ $<0.67, P<0.001)$ and UV chroma values $\left(0.34<R_{S}<0.83, P<0.001\right)$. For the iridescent patch, most parameters were correlated $\left(-0.37<R_{S}<0.87,0.001<P<0.93\right.$; see Supplementary material Table A2 for details). 


\section{Differences in color parameters between sessions}

An exploratory analysis using ANOVAs combined with Tukey multiple comparisons revealed that most mean values of color parameters were different between our three ringing sessions (Supplementary material Table A3). This was mainly due to the fact that data from the high breeding season in 2012 significantly differed from those from the low breeding season in 2012 and high breeding season in 2013, which generally did not differ from each other. However, the proportions of territorial and non-territorial individuals did not differ between sessions $\left(\chi^{2}=0.19, d f=2, P=0.91\right)$, nor did the proportions of females and males $\left(\chi_{2}^{2}=3.56, d f=2, P=0.17\right)$. In addition, body condition, wing chord and heterozygosity did not significantly differ between the three capture sessions. Before further analysis, color variables were therefore centered and scaled across ringing sessions (see Supplementary material for a discussion of this seasonal effect).

\section{Avian color discrimination of sexual dichromatism and of variation in plumage colour among individuals of the same sex}

To quantify sexual dichromatism and to estimate whether individuals perceive variation in plumage color among potential mates from the avian visual perspective, we computed the chromatic contrast of the reflectance spectra $(\Delta S$, Vorobyev et al. 1998) both between sexes, and within each sex, using the mean spectrum for the three measures (or six, for the right and left iridescent patches and dark streaks) per individual. We used the pavo package (Maia et al. 2013) developed for the R software (v. 2.101; R Core Team 2011) to run these analyses. We created a visual model (vismodel function) using the spectral sensitivity data from the Rock pigeon (Columba livia, Bowmaker et al. 1997) - i.e. $\lambda_{\max }=409 \mathrm{~nm}, 453 \mathrm{~nm}, 507 \mathrm{~nm}$ and $568 \mathrm{~nm}$ for wavelength of maximum absorbance for each cone, and $\lambda_{\text {cut }}=445 \mathrm{~nm}, 513$ $\mathrm{nm}, 539 \mathrm{~nm}$ and $570 \mathrm{~nm}$ for "cut-off" wavelength of oil droplets of C-, Y- (ventral retina form), Y(dorsal retina form) and R-type cones, respectively. The illuminant considered was an ideal white one, default option of the R function. The coldist function was used to estimate distances $(\Delta S)$ between (i) all pairs of male/female and (ii) all pairs of individuals within each sex for each measured body part. Following Vorobyev et al. (1998), we used the tetrachromatic photoreceptor 
densities ratio $1: 1: 1: 2$, and 0.1 as the Weber fraction. The distance in avian color space $\Delta S$ is expressed in just noticeable difference (jnd), with $\Delta S=1$ considered as the threshold of color discrimination. When $\Delta S<1$, two colors are indistinguishable. Above that threshold, the higher the value, the more discernible the two colors, discrimination being barely accurate under ideal conditions for low values above one jnd (Siddiqi et al. 2004). Analyses were also conducted on each session separately (Supplementary material Fig. A5 and A6), without any marked discrepancy with the results of the global analyses presented below.

\section{Statistical analyses}

Analyses were carried out using the R software (v. 2.101; R Core Team 2011). Correlation analyses used Pearson product-moment correlations or Spearman rank-order correlations. The relationship between body condition and feather coloration was tested by computing the scaled mass index proposed by Peig and Green (2009), using tarsus length as a linear body measurement of individuals. Each group of correlated color variables were tested for differences related to sex, territorial status, heterozygosity level, wing chord and body condition, as well as two-way interactions, through performing backward stepwise MANOVAs. Interactions were included to account for the fact that relationships between heterozygosity level, body size (wing chord) and condition tend to differ according to the sex and social status of individuals (Quinard et al. 2014). To that end, we used the manova function with the Wilks test option, followed by the corresponding ANOVAs using the aov function. The assumptions of ANOVAs and MANOVAs (multivariate normality, homogeneity of variances, equality of covariance matrices, absence of outliers) were generally fulfilled on the raw variables (few minor deviations to normality and homogeneity of variances) and checked on residuals of the models. Because Bonferroni correction is a highly conservative method of significance level adjustment (Narum 2006), we used the modified false discovery rate (BY-FDR correction) proposed by Benjamini and Yekutieli (2001) when conducting MANOVAs and ANOVAs.

\section{Results}

An overall slight sexual dichromatism was found for hue, with crown and breast being more reddish in males than in females (Table 1, Supplementary material Fig. A2). There was also an effect of the 
interaction between sex and wing chord on hue (Table 1), with females with longer wing chord being significantly more reddish on the crown (slope estimate $=-0.10, \pm$ s.e. $=0.02, t=-5.13, P<0.001$, Fig. 2a), whereas no significant relationship between hue and wing chord was found in males for the crown (slope estimate $=-0.01, \pm$ s.e. $=0.01, t=-0.88, P=0.38$, Fig. $2 b$ ). There was also a significant overall effect of territorial status on hue: individuals feeding in groups at Roberts were more reddish on the mantle and slightly more reddish on the crown, and tended to be less reddish on the breast (Table 1) than territorial individuals from Holetown. In addition, territorial individuals were overall brighter (for the crown, breast and belly, and marginally for the dark streak, Table 2, Supplementary material Fig. A3) and relatively brighter in the UV part of the spectra (for the breast and belly, Table 3), whereas they were relatively less bright in the yellow-red part (for the breast and belly, Table 4). There was also a tendency for an effect of the interaction between sex and heterozygosity on yellow-red chroma (Table 4) with more heterozygous males being significantly relatively brighter in the yellow-red part of the spectra on the mantle (slope estimate $=2.19, \pm 1.05, \mathrm{t}=2.09, P=0.04$, Fig. $2 \mathrm{k}$ ) and the belly (slope estimate $=2.49, \pm$ 1.00, t $=2.48, P=0.02$, Fig. $2 \mathrm{~m}$ ), but not females (mantle, slope estimate $=-1.57, \pm=0.96, \mathrm{t}=-1.63, P=$ 0.11 ; belly, slope estimate $=-0.34, \pm 1.01, \mathrm{t}=0.33, P=0.74$; Fig. 21). Crown brightness varied according to body condition as well (Table 2, Fig. 2c), with brighter individuals being in slightly better body condition (linear regression: slope estimate $=0.01, \pm$ s.e. $=0.006, t=2.67, P=0.009$ ).

Both wing chord and the interaction between territorial status and body condition had a significant overall effect on the color parameters of iridescent patches, which did not differ between the sexes (Table 5). Larger individuals were brighter and tended to have greater UV and blue chromas, whereas they tended to have a lower red chroma (Table 5, Fig. $2 \mathrm{~d}$, e, f and g), i.e. they were relatively brighter in the UV and blue parts of the spectrum than in the red. The iridescent patch of territorial individuals tended to be brighter with increasing body condition (slope estimate $=0.02, \pm$ s.e. $=0.008, t=$ 2.27, $P=0.03$, Fig. $2 \mathrm{~h}$ ), whereas the reverse was observed in non-territorial individuals (slope estimate $=$ $-0.02, \pm$ s.e. $=0.008, t=-2.70, P=0.009$, Fig. $2 \mathrm{i})$.

Finally, the avian color discrimination analyses highlighted
that Zenaida doves are unable to perceive sex-related differences in
brown plumage, as means and standard deviations are under or close to
the threshold of discrimination $\Delta S=1$ (Supplementary material Table A4, Fig.3). Although the difference between males and females for both dark streaks and iridescent patches was more pronounced (Supplementary material Table A4, Fig.3), it appeared slightly distinguishable with values < 
4 jnds (Siddiqi et al. 2004). From a sexual selection perspective, color discrimination analyses also showed that individuals are able to discriminate among potential mates on the basis of their plumage color for the iridescent patch, but not for the other colors assessed in this study (Supplementary material Table A4). This was the case for both females and males (Supplementary material Fig. A4a and b, respectively).

\section{Discussion}

Our study of the plumage colour of Zenaida doves in Barbados detected a slight sexual dichromatism in the pigment-based colored areas when considering hue, brightness and yellow-red chroma, but not in the iridescent patches for brightness, chroma or spectral position of the peaks. However, when taking avian vision into account, it appeared that individuals should not be able to perceive between- or within-sex differences in pigment-based colored plumage, but should be able to discriminate between individuals based on their iridescent colorations. In addition, variation in the plumage colour of Zenaida doves was found to be associated with several variables, suggesting that it may function as an indicator of individual quality in both males and females.

Spectrometry revealed an overall minor sexual dichromatism for hue in the pigmented plumage, with males being on average slightly more reddish than females. However, there was an extensive overlap between males and females, such that, contrary to what has been suggested in field guides and in the literature (Wiley 1991, del Hoyo et al. 1997, Gibbs et al. 2001, Sol et al. 2005), sexing by the human eye is definitely unreliable, as previously suggested by Monceau et al. (2011). In addition, our assessment of the difference between male and female plumage coloration using a visual model indicates that birds should not be able to distinguish the sex of their conspecifics based on the overall pigment-based coloration of the plumage.

Our results also tend to invalidate the claim made by some authors (Wiley 1991, del Hoyo et al. 1997), that females exhibit no or much reduced iridescent patches. Indeed, we found that, at least in the Barbados population of Zenaida doves, chroma and spectral position of the different peaks and brightness of iridescent patches did not differ significantly between sexes. Although we did not measure the actual size of iridescent patches, they did not appear to differ remarkably between males and females when observing tagged individuals of known sex in the field. However, because we measured birds in the field, our results may have to be confirmed by more precise measurements (see Meadows et al. 2011). Yet, taking into account the avian visual abilities, the spectral variation of iridescent patches appeared to be 
distinguishable by birds, albeit slightly. To our knowledge, only two studies assessed the degree of sexual dichromatism for iridescent plumage in Columbidae. Similarly to our results, both the black- bluish stripe on the Picui dove's wing coverts (Mahler and Kempenaers 2002) and iridescent neck feathers in pigeons (Leclaire et al. 2014) appear to be similar or only slightly different between sexes to the human eye, while the analysis of reflectance spectra shows significant differences between males and females spectra with an overlap between sexes. In addition, male pigeons were found to be unable to recognize the sex of conspecifics and to court every individual (Burley 1981). Interestingly, our results and these observations might explain why both male and female Zenaida doves chase all intruders, irrespective of their sex, during territorial defense (Quinard et Cézilly 2012).

The absence of strong differences between sexes for ornaments such as iridescent colorations is open to alternative explanations. Female ornamentation in Zenaida doves may have evolved to become similar to that of males. The mutual selection hypothesis suggests ornamentation in monogamous species is the result of selection for its expression in both sexes (Johnstone et al. 1996, Johnstone 1997) through three possible processes: (i) mate choice and mate competition, (ii) competition for other resources than mates and (iii) sexual selection for sexual mimicry. In particular, Burley (1986) predicted that mutual sexual selection should appear in monogamous species with biparental care. Accordingly, Zenaida doves maintain long-term monogamous pair-bonds and show shared territorial defense (Quinard and Cézilly 2012), joint anti-predatory vigilance (Cézilly and Keddar 2012) and bi-parental care (Wiley 1991, F. Cézilly unpublish. data,). In addition, Owens and Hartley (1998) evidenced a positive relationship between dichromatism for structural coloration and frequency of extra-pair paternity in monogamous bird species, which could be consistent with the very low, if any, level of extra-pair copulation observed in our population (FC, personal observations).

Alternatively, similarity in plumage coloration between the two sexes might simply be a genetically correlated response in one sex, male or female, to selection in the other sex (Lande 1980, Roulin and Jensen 2015, but see Gluckman 2014). In such a case, one would expect to observe a negative relationship between fitness and the intensity of plumage coloration in one sex and a positive one in the other one (Fitzpatrick et al. 1995, Roulin et al. 2010), if color entails production or maintenance costs, which may be the case with iridescent colors (Dyck 1987, Eliason and Shawkey 2011, Meadows et al. 2012). Although we did not assess the consequences of variation in plumage coloration in terms of survival or reproductive output here, we did not detect sex-related differences in the relationship between plumage coloration and body condition. Genetic theories of sexual selection predict that most ornamental 
secondary sexual traits provide reliable indication of the genetic quality of their bearers (Brown 1997, Fromhage et al. 2009). Although direct relationships between coloration and genome-wide heterozygosity or level of inbreeding have been evidenced in birds (García-Navas et al. 2009, Bolund et al. 2010, Ferrer et al. 2015) and neutral locus heterozygosity is known to influence adult survival in our species (Cézilly et al. 2016), we found only moderate evidence for a relationship between plumage coloration and individual heterozygosity in the Zenaida dove. However, ornaments could be linked to other aspects of genetic quality such as MHC diversity (von Schantz et al. 1996, Grahn 2000, Dunn et al. 2013, Whittingham et al. 2015). Another possibility is that sexually selected ornaments are condition-dependent and are thus more informative of the phenotypic quality of individuals than of their genetic one (Bonduriansky 2007). Alternatively, the signal may include a behavioral component, which we did not assess here, and which may enhance the attractiveness of the ornamental trait (Hasson 1989, Galván 2008, Byers et al. 2010). This might be the case in Zenaida doves, in which males shake their head while females outstretch their neck during courtship displays (Wiley 1991).

Observed relationships between some individual characteristics and color parameters are however more suggestive of direct benefits, with coloration acting as an honest signal of phenotypic quality in the Zenaida dove. Iridescent patches of larger individuals of both sexes were brighter, with relatively higher blue and smaller red peaks, and territorial individuals showed brighter iridescent patches when they were in better condition, while the reverse was true for non-territorial individuals. Our results are consistent with a number of studies that iridescent coloration covary with individual condition and size in birds (i.e. Doucet 2002, Møller and Petrie 2002, Doucet and Montgomerie 2003, Costa and Macedo 2005, Legagneux et al. 2010, Meadows et al. 2012), and suggest that iridescent color may have a signaling function. Iridescence may thus be used in mutual mate choice in Zenaida doves, or mediate agonistic intrasexual encounters during territorial defense (Doucet and Meadows 2009, Quinard and Cézilly 2012).

We also observed an overall difference in color between territorial individuals living in Holetown and non-territorial individuals feeding in flocks at the Roberts site. However, this difference may not necessarily reflect differences in phenotypic quality between the two groups, although such differences exist (Monceau et al. 2011). Roberts is an animal food factory, and birds foraging there are exposed to a certain amount of dust. It has been shown that soil principally causes a decrease in plumage UV chroma and brightness (Zampiga et al. 2004, Surmacki et al. 2007, Doucet and Hill 2009, Pérez-Rodriguez et al. 2011). Accordingly, we found that territorial individuals from Holetown were relatively brighter in the UV on the breast than individuals from the Roberts factory. In addition, air pollution is known to enhance 
melanin-based coloration (McGraw 2008), and individuals sampled at Roberts were indeed more reddish on the mantle, and marginally on the crown. Differences between individuals from Holetown and from Roberts were then probably related to the distinct environments of the sampling locations more than to the territorial status of individuals. It is not possible, however, to disentangle the effects of these two factors with our data set.

Further research is now required to confirm the role of plumage coloration in social signaling, mate choice and individual recognition in Zenaida dove. For instance, paired and unpaired territorial individuals could be compared to investigate mating patterns among natural pairs in the field, or coloration could be manipulated in controlled lab experiment of mate choice.

\section{Acknowledgements}

We are particularly grateful to Mr. Steve Devonish, Director of Natural Heritage (division of Ministry of Environment and Drainage of Barbados) and Kim Downes Agard for granting us the permission to capture, blood sample, and ring Zenaida doves. We thank the CRBPO, and particularly Olivier Dehorter, for kindly providing us with aluminium rings. We thank Carla Daniel for help in catching birds and Cyril Bhola for hospitality. The study was supported by the Agence Nationale pour la Recherche (programme blanc Monogamix), the Conseil Régional de Bourgogne, the CNRS, and the Institut Universitaire de France. Finally, we would like to thank the Subject Editor, Alexandre Roulin, and two reviewers for their detailed and helpful comments on previous versions of the manuscript. 


\section{References}

Andersson, M. B. 1994. Sexual selection. - Princeton Univ. Press.

Andersson, S., Örnborg, J. and Andersson, M. 1998. Ultraviolet sexual dimorphism and assortative mating in blue tits. - Proc. R. Soc. Lond. B Biol. Sci. 265: 445-450.

Andersson, S. and Prager, M. 2006. Quantification of coloration. - In: Hill, G. E. and McGraw, K. J. (eds), Bird Coloration, Vol. 1. Mechanisms and Measurements. Harvard Univ. Press, pp. 41-89.

Badyaev, A.V. and Hill, G. E. 2000. Evolution of sexual dichromatism: contribution of carotenoid- versus melanin-based coloration. - Biol. J. Linn. Soc. 69: 153-172.

Badyaev, A. V. and Hill, G. E. 2003. Avian sexual dichromatism in relation to phylogeny and ecology. Annu. Rev. Ecol. Evol. Syst. 34: 27-49.

Benjamini, Y. and Yekutieli, D. 2001. The control of the false discovery rate in multiple testing under dependency. - Ann. Stat. 29: 1165-1188.

Bókony V., Garamszegi L. Z., Hirschenhauser K. and Liker A. 2008. Testosterone and melanin-based black plumage coloration: a comparative study. - Behav. Ecol. Sociobiol. 62: 1229 - 1238.

Bolund, E., Martin, K., Kempenaers, B. and Forstmeier, W. 2010. Inbreeding depression of sexually selected traits and attractiveness in the zebra finch. - Anim. Behav. 79: 947-955.

Bond, J. 1993. A field guide to the birds of the West Indies. - Boston: Houghton Mifflin Harcourt.

Bonduriansky, R. 2007. The evolution of condition-dependent sexual dimorphism. - Am. Nat. 169: 9-19.

Bowmaker, J. K., Heath, L. A., Wilkie, S. E. and Hunt, D. M. 1997. Visual pigments and oil droplets from six classes of photoreceptor in the retinas of birds. - Vision Res. 37: 2183-2194.

Brommer, J.E., Ahola, K. and Karstinen, T. 2005. The colour of fitness: plumage coloration and lifetime reproductive success in the tawny owl. - Proc. R. Soc. B. 272: 935-940.

Brown, J. L. 1997. A theory of mate choice based on heterozygosity. - Behav. Ecol.8: 60-65.

Burley, N. 1981. The evolution of sexual indistinguishability. - In: Alexander, R. D. and Tinkle, D. W. (eds), Natural selection and social behaviour: recent research. Chiron Press.

Burley, N. 1986. Sexual selection for aesthetic traits in species with biparental care. - Am. Nat. 127: 415445.

Byers, J., Hebets, E. and Podos, J. 2010. Female mate choice based upon male motor performance. Anim. Behav. 79: 771-778. 
Carlier, P. and Lefebvre, L. 1996. Differences in individual learning between group-foraging and territorial Zenaida doves. - Behaviour 133:1197-1207.

Cézilly, F. and Keddar, I. 2012. Vigilance and food intake rate in paired and solitary Zenaida Doves Zenaida aurita. - Ibis 154: 161-166.

Cézilly, F., Quinard, A., Motreuil, S. and Pradel, R. 2016. Adult survival selection in relation to multilocus heterozygosity and body size in a tropical bird species, the Zenaida dove, Zenaida aurita. Oecologia 180: 127-136.

Chen, D. M., Collins, J. S. and Goldsmith, T. H. 1984. The ultraviolet receptor of bird retinas. - Science 225: $337-340$.

Costa, F. J. V. and Macedo, R. H. 2005. Coccidian oocyst parasitism in the blue-black grassquit: influence on secondary sex ornaments and body condition. - Anim. Behav. 70: 1401-1409.

Cserháti, P., Szél, A. and Röhlich, P. 1989. Four cone types characterized by anti-visual pigment antibodies in the pigeon retina. - Investig. Ophthalm. Vis. Sci. 30: 74-81.

Cuthill, I.C., Bennett, A.T.D., Partridge, J.C. and Maier, E.J. 1999. Plumage reflectance and the objective assessment of avian sexual dichromatism. - Am. Nat. 160: 183-200.

D’Alba, L., Van Hemert, C., Spencer, K.A., Heidinger, B.J., Gill, L., Evans, N.P., Monaghan, P., Handel, C.M. and Shawkey, M.D. 2014. Melanin-based color of plumage: role of condition and of feathers' microstructure. - Integr. Comp. Biol. 54: 633-644.

Darwin, C. R. 1871. The descent of man, and selection in relation to sex. - D. Appleton and Company.

Dechaume-Moncharmont, F. X., Monceau, K. and Cézilly, F. 2011. Sexing birds using discriminant function analysis: a critical appraisal. - Auk 128: 78-86.

del Hoyo, J., Elliott, A. and Sargatal, J. 1997. Handbook of the Birds of the World. Volume 4: $\underline{\text { Sandgrouse to Cuckoos. - Lynx Edicions. }}$

Delhey, K. and Kempenaers, B. 2006. Age differences in blue tit Parus caeruleus plumage colour: withinindividual changes or colour-biased survival? - J. Avian Biol. 37: 339-348.

Dolman, C. S., Templeton, J. and Lefebvre, L. 1996. Mode of foraging competition is related to tutor preference in Zenaida aurita. - J. Comp. Psychol. 110:45-54.

Doucet, S. M. 2002. Structural plumage coloration, male body size, and condition in the Blue-Black Grassquit. - Condor 104: 30-38.

Doucet, S. M. and Montgomerie, R. 2003. Structural plumage colour and parasites in satin bowerbirds Ptilonorhynchus violaceus: implications for sexual selection. - J. Avian Biol. 34: 237-242. 
Doucet, S. M. and Hill, G. E. 2009. Do museum specimens accurately represent wild birds? A case study of carotenoid, melanin, and structural colours in long-tailed manakins Chiroxiphia linearis. - J. Avian Biol. 40: 146-156.

Doucet, S. M. and Meadows, M. G. 2009. Iridescence: a functional perspective. - J. R. Soc. Interface 6: S115-S132.

Dunn, P. O., Whittingham, L. A. and Pitcher, T. E. 2001. Mating systems, sperm competition, and the evolution of sexual dimorphism in birds. - Evolution 55: 161-175.

Dunn, P. O., Bollmer, J. L., Freeman-Gallant, C. R. and Whittingham, L. A. 2013. MHC variation is related to a sexually selected ornament, survival and parasite resistance in the common yellowthroat. - Evolution. 67: 679-687.

Dyck J. 1987. Structure and light reflection of green feathers of fruit doves (Ptilinopus spp.) and an imperial pigeon (Ducula concinna). - Biol. Skrift. 30: 2-43.

Eaton, M. D. 2005. Human vision fails to distinguish widespread sexual dichromatism among sexually "monochromatic" birds. - Proc. Natl. Acad. Sci. U. S. A. 102: 10942-10946.

Eliason C. M. and Shawkey M. D. 2011. Decreased hydrophobicity of iridescent feathers: a potential cost of shiny plumage. - J. Exp. Biol. 214(13): 2157-2163.

Endler, J. A. 1990. On the measurement and classification of color in studies of animal color patterns. Biol. J. Linn. Soc. 41: 315-352.

Ferrer, E. S., García-Navas, V., Bueno-Enciso, J., Sanz, J. J. and Ortego, J. 2015. Multiple sexual ornaments signal heterozygosity in male blue tits. - Biol. J. Linn. Soc. 115 : 364-375.

Figuerola, J. and Green, A. J. 2000. The evolution of sexual dimorphism in relation to mating patterns, cavity nesting, insularity and sympatry in the Anseriformes. - Funct. Ecol. 14: 701-710.

Fitzpatrick, S., Berglund, A. and Rosenqvist, G. 1995. Ornaments or offspring: costs to reproductive success restrict sexual selection processes. - Biol. J. Linn. Soc. 55: 251-260.

Fromhage, L., Kokko, H. and Reid, J.M. 2009. Evolution of mate choice for genome-wide heterozygosity. - Evolution 63: 684-694.

Galván, I. 2008. The importance of white on black: unmelanized plumage proportion predicts display complexity in birds. - Behav. Ecol. Sociobiol. 63: 303-311.

Galván, I. and Møller, A. P. 2013. Pheomelanin-Based Plumage Coloration Predicts Survival Rates in Birds. - Physiol. Biochem. Zool. 86: 184-192. 
García-Navas, V., Ortego, J. and Sanz, J. J. 2009. Heterozygosity-based assortative mating in blue tits (Cyanistes caeruleus): implications for the evolution of mate choice. Proc Biol Sci. 276: 2931-2940.

Gibbs, D., Barnes, E. and Cox, J. 2001. Pigeons and Doves: A Guide to the Pigeons and Doves of the World. - Yale Univ. Press.

Grahn, M. 2000. MHC genotype and ornamentation. In: Espmark, Y., Amundsen, T. \& Rosenqvist, G.(eds), Animal signals: signaling and signal design in animal communication. pp. 421-436. Tapir academic press, Trondheim.

Gluckman, T.L. 2014. Pathways to elaboration of sexual dimorphism in bird plumage patterns. - Biol. J. Linn. Soc. 111: 262-273.

Griffith S. C., Parker T. H. and. Olson V.A. 2006. Melanin- versus carotenoid-based sexual signals: Is the difference really so black and red? - Anim. Behav. 71: 749-763.

Guindre-Parker, S. and Love, O.P. 2014. Revisiting the condition-dependence of melanin-based plumage. - J. Avian Biol. 45: 29-33.

Hasson, O. 1989. Amplifiers and the handicap principle in sexual selection - a different emphasis. - Proc. R. Soc. Lond. B Biol. Sci. 235: 383-406.

Hõrak, P. and Maenniste, M. 2016. Viability selection affects black but not yellow plumage colour in greenfinches. - Oecologia 180: 23-32.

Hubbard, J.K., Uy, J.A.C., Hauber, M.E., Hoekstra, H.E. and Safran, R.J. 2010. Vertebrate pigmentation: from underlying genes to adaptive function. - Trends Ecol. Evol. 26: 231-239.

Hunt, S., Bennett, A. T. D., Cuthill, I. C. and Griffiths, R. 1998. Blue tits are ultraviolet tits. - Proc. R. Soc. Lond. B Biol. Sci. 265: 451-455.

Johnstone, R. A., Reynolds, J. D. and Deutsch, J. C. 1996. Mutual mate choice and sex differences in choosiness. - Evolution 50: 1382-1391.

Johnstone, R. A. 1997. The tactics of mutual mate choice and competitive search. - Behav. Ecol. Sociobiol. 40: 51-59.

Korsten, P., Dijkstra, T.H. and Komdeur, J. 2007. Is UV signalling involved in male-male territorial conflict in the blue tit (Cyanistes caeruleus)? A new experimental approach. - Behaviour 144: 447$\underline{470 .}$

Kruger, O. and Lindstrom, J. 2001. Lifetime reproductive success in common buzzard, Buteo buteo: from individual variation to population demography. - Oikos. 93:260-273. 
Lande, R. 1980. Sexual dimorphism, sexual selection, and adaptation in polygenic characters. - Evolution 34: $292-305$.

Leclaire, S., Pierret, P., Chatelain, M. and Gasparini, J. 2014. Feather bacterial load affects plumage condition, iridescent color, and investment in preening in pigeons. - Behav. Ecol. 25: 1192-1198.

Legagneux, P., Thery, M., Guillemain, M., Gomez, D. and Bretagnolle, V. 2010. Condition dependence of iridescent wing flash-marks in two species of dabbling ducks. - Behav. Process. 83: 324-330.

MacDougall, A.K. and Montgomerie, R. 2003. Assortative mating by carotenoid-based plumage colour: a quality indicator in American goldfinches, Carduelis tristis. -Naturwissenschaften 90: 464-467.

Maia, R. and Macedo, R.H. 2011. Achieving luster: prenuptial molt pattern predicts iridescent structural coloration in Blue-black Grassquits. - J. Ornithol. 152: 243-252.

Maia, R., Eliason, C. M., Bitton, P. P., Doucet, S. M. and Shawkey, M. D. 2013. pavo: an R Package for the analysis, visualization and organization of spectral data. - Methods Ecol. Evol. 4: 906-913.

Mahler, B. A. and Kempenaers, B. 2002. Objective assessment of sexual plumage dichromatism in the Picui Dove. - Condor 104: 248-254.

Mays, H. L., McGraw, K. J., Ritchison, G., Cooper, S., Rush, V. and Parker, R. S. 2004. Sexual dichromatism in the yellow-breasted chat Icteria virens. spectrophotometric analysis and biochemical basis. - J. Avian Biol. 35: 125-134.

McGraw, K. J. 2004. Multiple UV reflectance peaks in the iridescent neck feathers of pigeons. Naturwissenschaften 91: 125-129.

McGraw, K.J., Safran, R.J. and Wakamatsu, K. 2005. How feather colour reflects its melanin content. Funct. Ecol. 19: 816-821.

McGraw, K. J. 2008. An update on the honesty of melanin-based color signals in birds. - Pigm. Cell Melanoma R. 21: 133-138.

Meadows, M. G., Morehouse, N. I., Rutowski, R. L., Douglas, J. M. and McGraw, K. J. 2011. Quantifiying iridescent coloration in animals: a method for improving repeatability. - Behav. Ecol. Sociobiol. $65: 1317-1327$.

Meadows, M. G., Roudybush, T. E. and McGraw, K. J. 2012. Dietary protein level affects iridescent coloration in Anna's hummingbirds, Calypte anna. - J. Exp. Biol. 215: 2742-2750.

Mennill, D. J., Doucet, S. M., Montgomerie, R. and Ratcliffe, L. M. 2003. Achromatic color variation in black-capped chickadees, Poecile atricapilla: black and white signals of sex and rank. - Behav. Ecol. Sociobiol. 53: 350-357. 
Meunier, J., Figueiredo Pinto, S., Burri, R. and Roulin, A. 2011. Eumelanin-based coloration and fitness parameters in birds: a meta-analysis. - Behav. Ecol. Sociobiol. 65: 559-567.

Møller, A.P., Biard, C., Blount, J.D., Houston, D.C., Ninni, P., Saino, N. and Surai, P.F. 2000 Carotenoid-dependant signals: Indicators of foraging efficiency, immunocompetence or detoxification ability? - Avian Poultry Biol. Rev. 11: 137-159.

Møller, A. P. and Petrie, M. 2002. Condition dependence, multiple sexual signals, and immunocompetence in peacocks. - Behav. Ecol.13: 248-253.

Monceau, K. 2009. Biologie des populations de tourterelles à queue carrée sur l'île de la Barbade: Apports de l'outil moléculaire. - Dijon: Université de Bourgogne.

Monceau, K., Gaillard, M., Harrang, E., Santiago-Alarcon, D., Parker, P. G., Céilly, F. and Wattier, R. 2009. Twenty-three polymorphic microsatellite markers for the Caribbean endemic Zenaida dove, Zenaida aurita, and its conservation in related Zenaida species. - Conserv. Genet. 10: 1577-1581.

Monceau, K., Wattier, R., Dechaume-Moncharmont, F. X., Motreuil, S. and Cézilly, F. 2011. Territoriality versus flocking in the Zenaida dove (Zenaida aurita): resource polymorphism revisited using morphological and genetic analyses. - Auk 128: 15-25.

Montgomerie, R. 2006. Quantifying colors. - In: Hill, G. E. and McGraw, K. J. (eds), Bird Coloration, Vol. 1. Mechanisms and Measurements. Harvard Univ. Press, pp. 41-90.

Murphy, T.G. and Pham, T.T. 2012. Condition and brightness of structural blue-green motmot tail-racket brightness is related to speed of feather growth in males, but not in females. - Biol. J. Linn. Soc. 106: 673-681.

Murphy, Troy G., Hernandez-Mucino, D., Osorio-Beristain, M., Montgomerie, R. and Omland, K.E. 2009. Carotenoid-based status signaling by females in the tropical streak-backed oriole. - Behav. Ecol. 20: $1000-1006$.

Musgrove, A.B. and Wiebe, K.L. 2016. Condition-dependent expression of carotenoid- and melaninbased plumage colour of northern flicker nestlings revealed by manipulation of brood size. - J. Avian Biol., in press.

Narum, S. R. 2006. Beyond Bonferroni: Less conservative analyses for conservation genetics. - Conserv. Genet. 7: 783-787.

Negro J.J., Bortolotti G.R., Mateo R. and García I.M. 2009. Porphyrins and pheomelanins contribute to the reddish juvenal plumage of blackshouldered kites. - Comp. Biochem. Physiol. B 153: 296-299. 
Ödeen, A. and Håstad, O. 2013. The phylogenetic distribution of ultraviolet sensitivity in birds. - BMC Evol. Biol. 13: 36.

Osorio, D. and Ham, A.D. 2002 Spectral reflectance and directional properties of structural coloration in bird plumage. - J. Exp. Biol. 205: 2017-2027.

Owens, I. P. F. and Hartley, I. R. 1998. Sexual dimorphism in birds: why are there so many different forms of dimorphism? - Proc. R. Soc. Lond. B Biol. Sci. 265: 397-407.

Parker, T.H. 2013. What do we really know about the signalling role of plumage colour in blue tits? A case study of impediments to progress in evolutionary biology. - Biol. Rev. 88: 511-536.

Peig, J. and Green, A. J. 2009. New perspectives for estimating body condition from mass/length data: the scaled mass index as an alternative method. - Oikos 118: 1883-1891.

Pérez-Rodríguez, L., Mougeot, F. and Bortolotti, G. R. 2011. The effects of preen oils and soiling on the UV-visible reflectance of carotenoid-pigmented feathers. - Behav. Ecol. Sociobiol. 65: 1425-1435.

Peters, A., Delhey, K., Andersson, S., van Noordvjik, H. and Forschler, M.I. 2008. Condition-dependence of multiple carotenoid-based plumage traits: an experimental study. - Funct. Ecol. 22: 831-839.

Piault, R., van den Brink, V. and Roulin, A., 2012. Condition-dependent expression of melanin-based coloration in the Eurasian kestrel. - Naturwissenschaften 99: 391-396.

Quinard, A. and Cézilly, F. 2012. Sex roles during conspecific territorial defence in the Zenaida dove, Zenaida aurita. - Anim. Behav. 83: 47-54.

Quinard, A. 2013. Diversité génétique individuelle, différenciation morphologique et comportementale entre les sexes, patterns d'appariement et paramètres démographiques chez une espèce d'oiseau tropicale et monogame, la tourterelle à queue carrée, Zenaida aurita. - Ph. D. Thesis, Dijon: Université de Bourgogne. 196pp.

Quinard, A., Dechaume-Moncharmont, F.-X. and Cézilly, F. 2014. Pairing patterns in relation to body

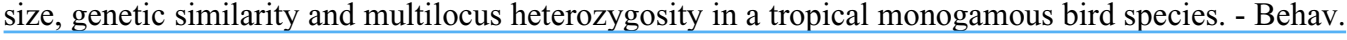
Ecol. Sociobiol. 68: 1723-1731.

Reudink, M.W., McKellar, A.E., Marini, K.L.D., McArthur, S.L., Marra, P.P. and Ratcliffe, L.M. 2015. Inter-annual variation in American redstart (Setophaga ruticilla) plumage colour is associated with rainfall and temperature during moult: an 11-year study. - Oecologia 178: 161-173. 


\section{Romeski, M. and Yager, D. 1976. Psychophysical studies of pigeon color}

\section{vision-II. The spectral photochromatic interval function. - Vision Res. 16:}

\section{7-512.}

Roulin, A. and Dijktra, C. 2003. Genetic and environmental components of variation in eumelanin and phaeomelanin traits in the barn owl. - Heredity 90: 359-364.

Roulin, A., Altwegg, R., Jensen, H., Steinsland, I. and Schaub, M. 2010. Sex-dependent selection on an autosomal melanic female ornament promotes the evolution of sex ratio bias. - Ecol. Lett. 13: 616$\underline{626}$

Roulin, A. 2016. Condition-dependence, pleiotropy and the handicap principle of sexual selection in melanin-based colouration. - Biol. Rev. 91: 328-348.

Roulin, A. and Jensen, H. 2015. Sex-linked inheritance, genetic correlations and sexual dimorphism in three melanin-based colour traits in the barn owl. - J. Evol. Biol. 28: 655-666.

Rousset, F. 2011. Genepop 4.1 for Windows/Linux/Mac OS X

Scott, D.K. and Clutton-Brock, T.H. 1990. Mating systems, parasites and plumage dimorphism in waterfowl. - Behav. Ecol. Sociobiol. 26: 261-273.

Shawkey, M.D., Estes, A.M., Siefferman, L.M. and Hill, G.E. 2005. The anatomical basis of sexual dichromatism in non-iridescent ultraviolet-blue structural coloration of feathers. - Biol. J. Linn. Soc. 84: 259-271.

Siddiqi, A., Cronin, T. W., Loew, E. R., Vorobyev, M. and Summers, K. 2004. Interspecific and intraspecific views of color signals in the strawberry poison frog Dendrobates pumillo. - J. Exp. Biol. 207: 2471-2485.

Siefferman, L., Hill, G.E. and Dobson, F.S. 2005. Ornamental plumage coloration and condition are dependent on age in eastern bluebirds Sialia sialis. - J. Avian Biol. 36: 428-435.

Sol, D., Elie, M., Marcoux, M., Chrostovsky, E., Porcher, C. and Lefebvre, L. 2005. Ecological mechanisms of a resource polymorphism in Zenaida Doves of Barbados. - Ecology 86: 2397-2407.

Surmacki, A. and Nowakowski, J. K. 2007. Soil and preen waxes influence the expression of carotenoidbased plumage coloration. - Naturwissenschaften 94: 829-835.

Szulkin, M., Bierne, N. and David, P. 2010. Heterozygosity-fitness correlations: a time for reappraisal. Evolution 64: 1202-1217. 
Taysom A.J., Stuart-Fox D. and Cardoso G.C. 2011. The contribution of structural-, psittacofulvin- and melanin-based colouration to sexual dichromatism in Australasian parrots. - J. Evol. Biol. 24: 303313.

von Schantz, T., Wittzell, H., Göransson, G., Grahn, M. and Persson, K. 1996. MHC genotype and male ornamentation: genetic evidence for the Hamilton-Zuk model. - Proc. Biol. Sci. 263: 265-71.

Vorobyev, M., Osorio, D., Bennett, A. T. D., Marshall, N. J. and Cuthill, C. 1998. Tetrachromacy, oil droplets and bird plumage colours. - J. Comp. Physiol. A. 183: 621-633.

Wiley, J. W. 1991. Ecology and behavior of the Zenaida dove. - Ornitol. Neotrop. 2: 49-75.

Whittingham, L. A., Freeman-Gallant, C. R., Taff, C. C. and Dunn, P. O. 2015. Different ornaments signal male health and MHC variation in two populations of a warbler. - Mol. Ecol. 24: 1584-1595.

Yin, H., Shi, L., Sha, J., Li, Y., Qin, Y., Dong, B., Meyer, S., Liu, X., Zhao, L. and Zi, J. 2006. Iridescence in the neck feathers of domestic pigeons. - Phys. Rev. E. Stat. Nonlin. Soft. Matter. Phys. 74:051916.

Yoshioka, S., Nakamura, E. and Kinoshita, S. 2007. Origin of two-color iridescence in rock dove's feather. - J. Phys. Soc. Jpn. 76:013801.

Zampiga, E., Hoi, H. and Pilastro, A. 2004. Preening, plumage reflectance and female choice in budgerigars. - Ethol. Ecol. Evol. 16: 339-349.

Supplementary material (Appendix JAV-XXXXX at <www.oikosoffice.lu.se/appendix $>$ ). 
Table legends

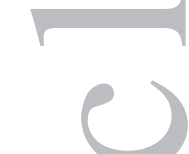

Table 1. Effects of sex, territorial status, wing chord and the interaction between sex and wing chord on hue parameters of pigment-based colored plumage areas in Zenaida dove. The effects of heterozygosity and body condition, initially included, were not retained in the final model. MANOVA Wilks' lambda and exact F statistics for the hypothesis of no overall effects on hue, and corresponding univariate tests for each body region are presented. The effect of sex estimates the difference between males taken as the reference and females. The effect of territorial status estimates the difference between territorial individuals taken as the reference and non territorial birds. P-values in bold are significant at $P<0.0125$ after a BY-FDR correction. Significant relationships are illustrated in Fig. 2a and b.

\begin{tabular}{|c|c|c|c|c|c|c|c|c|c|c|c|c|c|c|c|}
\hline Hue & Sex & 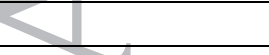 & & Territorial & status & & & Wing chor & & & & Sex $\times$ Win & chord & & \\
\hline \multirow[t]{2}{*}{$\begin{array}{l}\text { Wilks' } \\
\text { lambda }\end{array}$} & 0.6535 & & & 0.8707 & & & & 0.8395 & & & & 0.8697 & & & \\
\hline & $F_{\mathrm{df}}$ & Estimate & \pm s.e. & $F_{\mathrm{df}}$ & $P$ & Estimate & \pm s.e. & $F_{\mathrm{df}}$ & $P$ & Estimate & \pm s.e. & $F_{\mathrm{df}}$ & $P$ & Estimate & \pm s.e. \\
\hline MANOVA & $4.65_{4,114}$ & $<0.001$ & & $4.25_{4,114}$ & 0.003 & & & $8.88_{4,114}$ & $<0.001$ & & & $4.27_{4,114}$ & 0.002 & & \\
\hline Crown & $10.95_{1,117}$ & $\mathbf{0 . 0 0 1}-13.62$ & 4.11 & $4.97_{1,117}$ & 0.02 & 0.33 & 0.14 & $24.65_{1,117}$ & $<0.001$ & -0.10 & 0.02 & $9.95_{1,117}$ & 0.002 & 0.08 & 0.02 \\
\hline Mantle & $0.0004_{1,117}$ & $0.98 \quad 0.09$ & 4.88 & $12.36_{1,117}$ & $<0.001$ & 0.62 & 0.17 & $0.07_{1,117}$ & 0.77 & -0.007 & 0.02 & $0_{1,117}$ & 0.99 & -0.0001 & 0.03 \\
\hline Breast & $2.56_{1,117}$ & $<0.001-7.47$ & 4.66 & $3.99_{1,117}$ & 0.04 & -0.33 & 0.16 & $5.85_{1,117}$ & 0.01 & -0.05 & 0.02 & $2.21_{1,117}$ & 0.13 & 0.04 & 0.03 \\
\hline Belly & $1.52_{1,117}$ & $0.21 \quad 6.17$ & 4.99 & $0.75_{1,117}$ & 0.38 & 0.15 & 0.18 & $0.15_{1,117}$ & 0.69 & 0.009 & 0.02 & $1.67_{1,117}$ & 0.19 & -0.04 & 0.03 \\
\hline
\end{tabular}




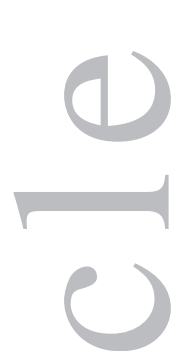

Table 2. Effect of body condition and territorial status on brightness parameters of pigment-based colored plumage areas in Zenaida dove. The effects of sex, heterozygosity and body size (wing chord), initially included, were not retained in the final model. MANOVA Wilks' lambda and exact F statistics for the hypothesis of no overall effects on brightness, and corresponding univariate tests for each body region are presented. The effect of territorial status estimates the difference between territorial individuals taken as the reference and non territorial birds. P-values in bold are significant at $P<0.0125$ after a BY-FDR correction. The significant relationship between crown brightness and body conditions is illustrated in Fig. 2 c.

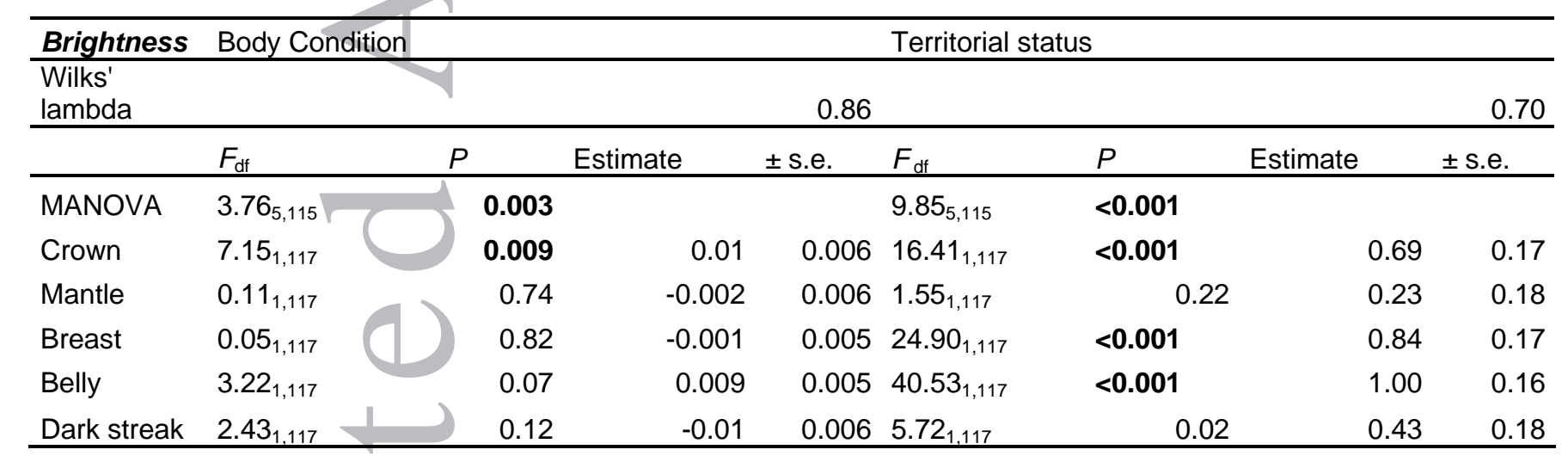




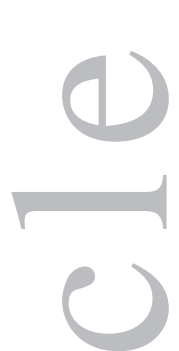

Table 3. Effect of territorial status on UV chroma parameters of pigment-based colored plumage areas in Zenaida dove. The effects of sex, heterozygosity, body size (wing chord) and body condition, initially included, were not retained in the final model. MANOVA Wilks' lambda and exact F statistics for the hypothesis of no overall effects on UV chroma, and corresponding univariate tests for each body region are presented. The effect of territorial status estimates the difference between territorial individuals taken as the reference and non territorial birds. P-values in bold are significant at $P<0.0125$ after a BY-FDR correction.

\begin{tabular}{|c|c|c|c|c|}
\hline \multirow{3}{*}{$\begin{array}{l}\text { UV chroma } \\
\text { Wilks' lambda }\end{array}$} & \multicolumn{4}{|c|}{ Territorial status } \\
\hline & \multicolumn{4}{|l|}{0.80} \\
\hline & $F_{\mathrm{df}}$ & $P$ & Estimate & \pm s.e. \\
\hline MANOVA & \multicolumn{4}{|c|}{$7.07_{4,117}<0.001$} \\
\hline Crown & $1.39_{1,120}$ & 0.23 & 0.22 & 0.18 \\
\hline Mantle & $0.24_{1,120}$ & 0.63 & 0.09 & 0.18 \\
\hline Breast & $14.61_{1,120}$ & $<0.001$ & 0.66 & 0.18 \\
\hline Belly & $26.20_{1,120}$ & $<0.001$ & 0.85 & 0.16 \\
\hline
\end{tabular}




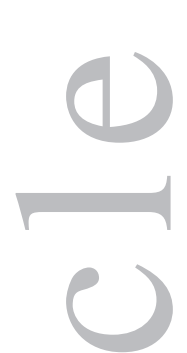

Table 4. Effect of sex, heterozygosity, territorial status and the interaction between sex and heterozygosity on yellow-red chroma parameters of pigment-based colored एᄆ

plumage areas in Zenaida dove. The effects of body size (wing chord) and body condition, initially included, were not retained in the final model. MANOVA Wilks' lambda and exact $\mathrm{F}$ statistics for the hypothesis of no overall effects on UV chroma, and corresponding univariate tests for each body region are presented. The effect of sex estimates the difference between males taken as the reference, and females. The effect of territorial status estimates the difference between territorial individuals taken as the reference and non territorial birds. P-values in bold are significant at $\mathrm{P}<0.0125$ after a BY-FDR correction. Significant relationships are illustrated in Fig. $2 \mathrm{j}$ to $\mathrm{m}$.

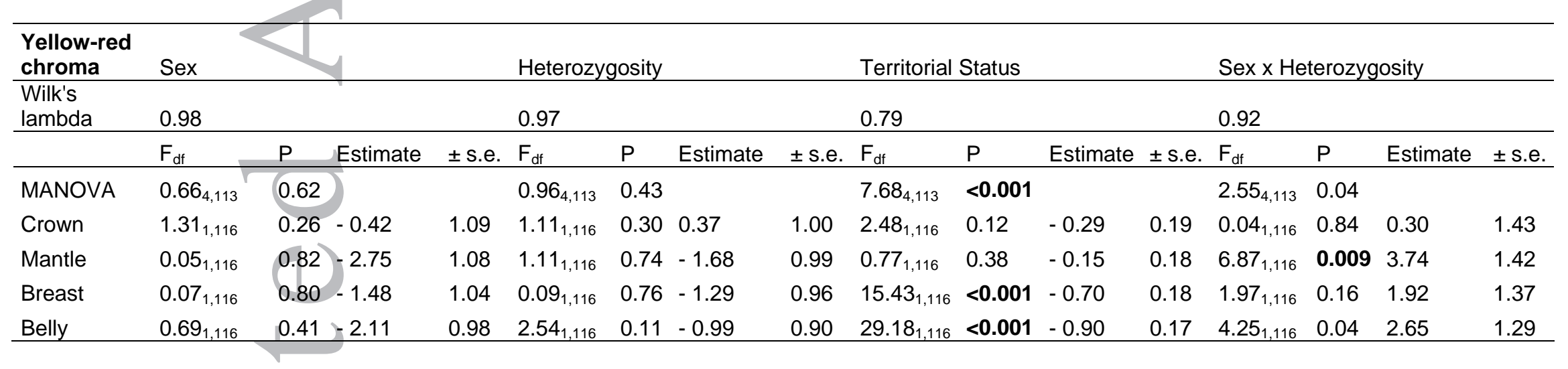




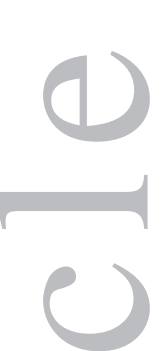

Table 5. Effect of territorial status, body condition, wing chord and the interaction between territorial status and body condition on parameters of the iridescent plumage patch

$$
\text { rar }
$$

in Zenaida dove. The effects of sex and heterozygosity, initially included, were not retained in the final model. MANOVA Wilks' lambda and exact F statistics for the hypothesis of no overall effects on the color of the iridescent patch, and corresponding univariate tests for each color parameter are presented. The effect of territorial status estimates the difference between territorial individuals taken as the reference and non territorial birds. $P$-values in bold are significant at $P<0.0125$ after a BY-FDR correction. Significant relationships are illustrated in Fig. 2d to i.

\begin{tabular}{|c|c|c|c|c|c|c|c|c|c|c|c|c|c|c|c|}
\hline $\begin{array}{l}\text { Iridescent } \\
\text { patch }\end{array}$ & Territorial status & & & Body con & dition & & & Wing chorc & & & & Territorial & tatus $\times$ B & 3ody conditi & tion \\
\hline \multirow[t]{2}{*}{ Wilks' lambda } & 0.94 & & & 0.91 & & & & 0.79 & & & & 0.82 & & & \\
\hline & $F_{\mathrm{df}}$ & Estimate & \pm s.e. & $F_{\mathrm{df}}$ & $P$ & Estimate & \pm s.e. & $F_{\mathrm{df}}$ & $P$ & Estimate & \pm s.e. & $F_{\mathrm{df}}$ & $P$ & Estimate & \pm s.e. \\
\hline MANOVA & $1.09_{7,111}$ & & & $1.53_{7,111}$ & 0.16 & & & $4.22_{7,111}$ & $<0.001$ & & & $3.59_{7,111}$ & 0.002 & & \\
\hline Brightness & $2.17_{1,117}$ & -5.79 & 1.82 & $2.74_{1,117}$ & 0.10 & -0.72 & 0.02 & $12.01_{1,117}$ & $<0.001$ & 0.24 & 0.11 & $14.42_{1,117}$ & $<0.001$ & 0.09 & 0.05 \\
\hline $\begin{array}{l}\text { UV chroma } \\
\text { UV spectral }\end{array}$ & $0.21_{1,117}$ & 1.79 & -0.16 & $0.49_{1,117}$ & 0.48 & -0.004 & 0.009 & $8.43_{1,117}$ & 0.01 & 0.06 & 0.02 & $5.67_{1,117}$ & 0.09 & 0.03 & 0.01 \\
\hline position & $0.35_{1,117}$ & -6.83 & 11.73 & $0.12_{1,117}$ & 0.73 & -0.04 & 0.06 & $1.09_{1,117}$ & 0.30 & 0.11 & 0.10 & $0.42_{1,117}$ & 0.52 & 0.05 & 0.08 \\
\hline $\begin{array}{l}\text { Blue chroma } \\
\text { Blue spectral }\end{array}$ & $1.09_{1,117} \quad 0.29$ & -0.11 & 0.04 & $1.07_{1,117}$ & 0.30 & $-<0.001$ & $<0.001$ & $6.78_{1,117}$ & 0.01 & $<0.001$ & $<0.001$ & $3.26_{1,117}$ & 0.17 & $<0.001$ & $<0.001$ \\
\hline position & $0.02_{1,117}-0.90$ & 9.59 & 20.30 & $0.24_{1,117}$ & 0.63 & 0.07 & 0.11 & $0.25_{1,117}$ & 0.62 & 0.09 & 0.18 & $0.24_{1,117}$ & 0.63 & -0.07 & 0.14 \\
\hline $\begin{array}{l}\text { Red chroma } \\
\text { Red spectral }\end{array}$ & $0.49_{1,117} \quad 0.49$ & 0.07 & 0.07 & $0.95_{1,117}$ & 0.33 & $<0.001$ & $<0.001$ & $11.17_{1,117}$ & 0.001 & $-<0.001$ & $<0.001$ & $4.58_{1,117}$ & 0.05 & $-<0.001$ & $<0.001$ \\
\hline position & $0.78_{1,117} \quad 0.38$ & -6.49 & 3.26 & $0.001_{1,117}$ & 0.97 & -0.03 & 0.02 & $3.52_{1,117}$ & 0.08 & 0.03 & 0.03 & $0.26_{1,117}$ & 0.64 & 0.05 & 0.02 \\
\hline
\end{tabular}




\section{Figure Legends}

Figure 1. Adult Zenaida dove (a) in Sunset Crest, Holetown, Barbados, (b) focus on the head, iridescent patch and lower dark streak.

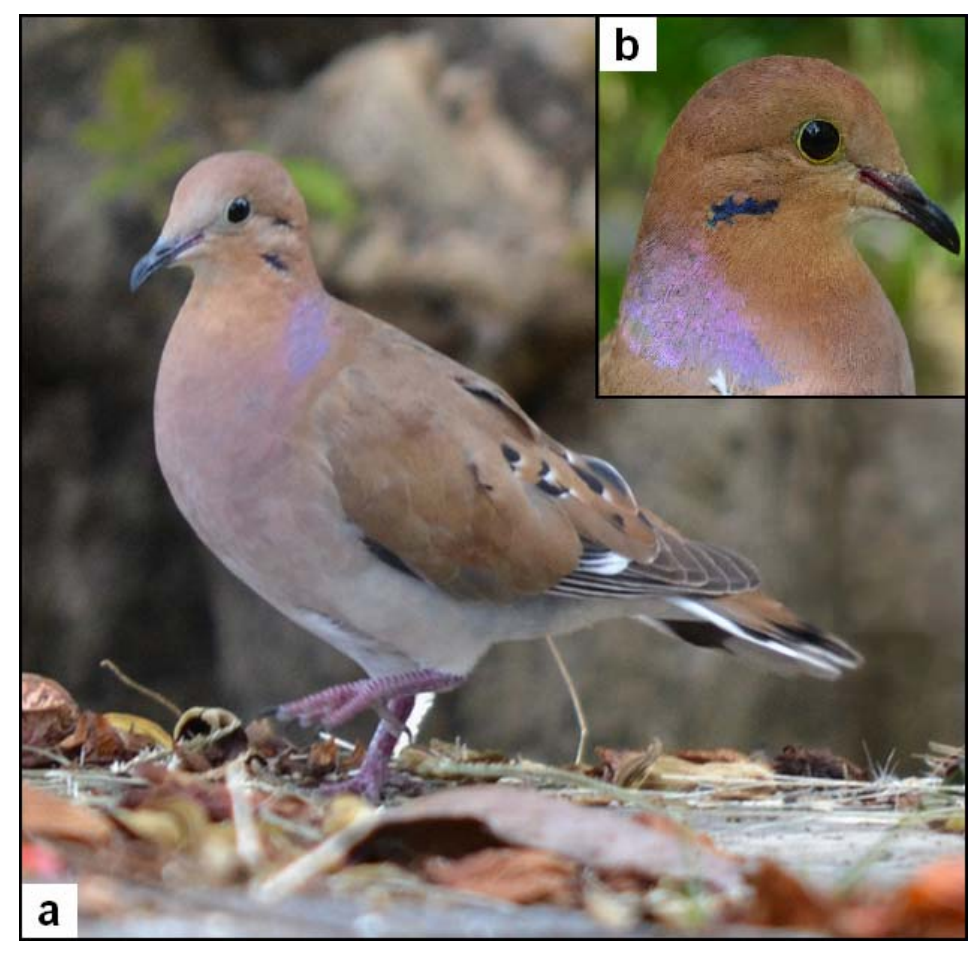


Figure 2. Scatter plots with trend lines in dashed for significant relationships between wing chord and hue of the crown in (a) females and (b) males, (c) body condition and brightness of the crown, (d) wing chord and brightness of the iridescent patches, (e) wing chord and UV chroma of the iridescent patches, (f) wing chord and blue chroma of the iridescent patches, (g) wing chord and red chroma of the iridescent patches, and wing chord and brightness of the iridescent patches in (h) territorial individuals and (i) non-territorial individuals, and heterozygosity level and yellow-red chroma of the mantle in (j) females and (k) males, and of the belly in (l) females and (m) males (see text and Tables 1 to 5 for details). 

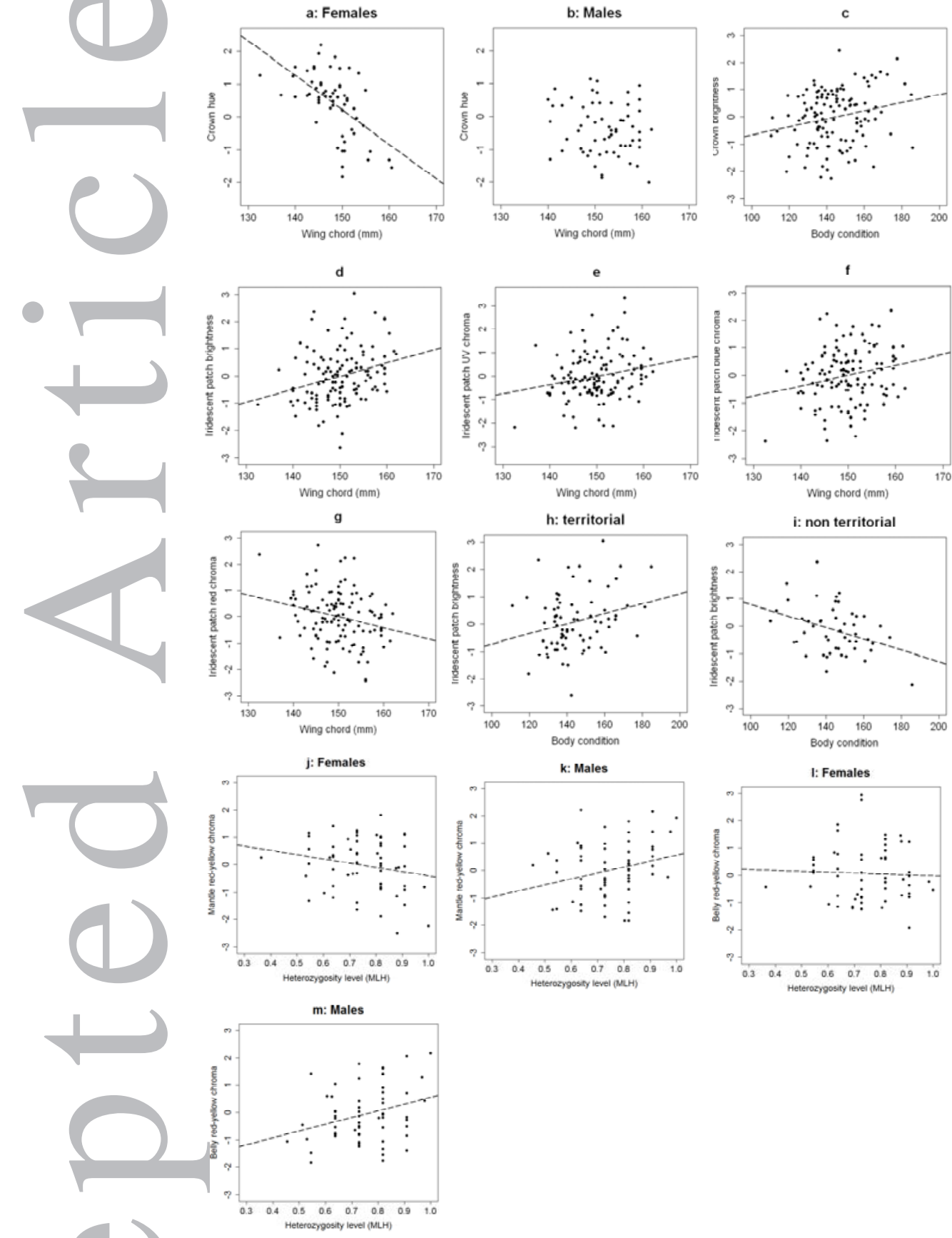

Figure 3. Plot of color distances $\Delta S$ in units of just noticeable differences (JNDs) between males and females, as viewed by rock dove visual system. Dots and error bars indicate mean \pm standard deviation chromatic distances between all pairs of different sexes. The dashed line marks JND $=1$ above which the pair of color patches is considered to be discernible by birds. 


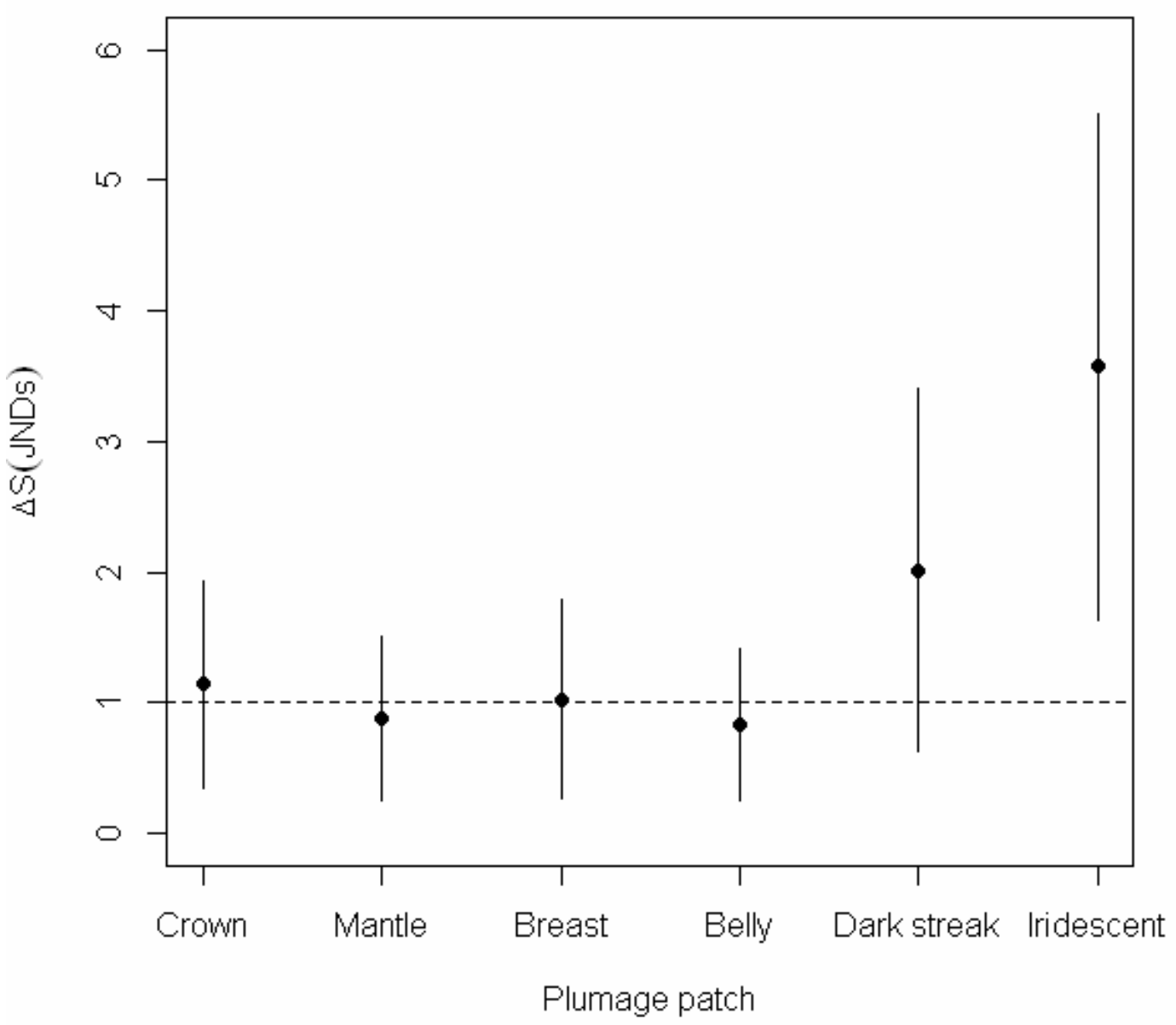

